\title{
Bibliometric analysis of leishmaniasis research in Medline (1945-2010)
}

José M Ramos ${ }^{1,2^{*}}$, Gregorio González-Alcaide ${ }^{3}$ and Máxima Bolaños-Pizarro ${ }^{4}$

\begin{abstract}
Background: Publications are often used as a measure of success of research work. Leishmaniasis is considered endemic in 98 countries, most of which are developing. This article describes a bibliometric review of the literature on leishmaniasis research indexed in PubMed during a 66-year period.

Methods: Medline was used via the PubMed online service of the US National Library of Medicine. The search strategy was Leishmania [MeSH] or leishmaniasis [MeSH] from 1 January 1945 until 31 December 2010. Neither language nor document type restrictions were employed.
\end{abstract}

Results: A total of 20,780 references were retrieved. The number of publications increased steadily over time, with 3,380 publications from 1945-1980 to 8,267 from 2001-2010. Leishmaniasis documents were published in 1,846 scientific journals, and Transactions of the Royal Society of Tropical Medicine and Hygiene (4.9\%) was the top one. The USA was the predominant country by considering the first author's institutional address (16.8\%), followed by Brazil (14.9\%), and then India (9.0\%), however Brazil leads the scientific output in 2001-2010 period (18.5\%), followed by the USA (13.5\%) and India (10\%). The production ranking changed when the number of publications was normalised by population (Israel and Switzerland), by gross domestic product (Nepal and Tunisia), and by gross national income per capita (India and Ethiopia). For geographical area, Europe led (31.7\%), followed by Latin America (24.5\%).

Conclusions: We have found an increase in the number of publications in the field of leishmaniasis. The USA and Brazil led scientific production on leishmaniasis research.

Keywords: Leishmaniasis, Leishmania, Bibliometry, Scientific production, Mapping, Leishmaniasis visceral, Leishmaniasis cutaneous, Leishmaniasis mucocutaneous, Diffuse cutaneous Leishmaniasis

\section{Background}

Leishmaniasis is a group of diseases caused by protozoan parasites of the Leishmania genus, order Kinetoplastida. More than 20 Leishmania species are considered human pathogens. Leishmaniasis occurs on four continents and is considered endemic in 98 countries and three territories, most of which are low- and middle-income [1,2].

Leishmaniasis is a poverty-related disease in which poverty and disease reinforce each other in a vicious cycle. Poverty determinants like malnutrition, displacement, poor housing, illiteracy, gender discrimination, immune system

\footnotetext{
* Correspondence: jramosrincon@yahoo.es

'Department of Internal Medicine, Hospital General Universitario de Alicante, Alicante, Spain

${ }^{2}$ Department of Medicine, Universidad Miguel Hernández de Elche, Alicante, Spain

Full list of author information is available at the end of the article
}

weakness, and lack of resources have been reviewed elsewhere [3]. Leishmaniasis is still one of the world's most neglected diseases; 350 million people are considered at risk of contracting leishmaniasis, and some 1 million new cases occur yearly [2]. In the past 10 years, there have been major scientific breakthroughs in the treatment, diagnosis and prevention of leishmaniasis, and the cost of several key medicines has been reduced $[4,5]$.

Research is important in a country's development and progress. Biomedical research projects usually lead to publications in the serial literature. Original articles allow investigators to present their scientific observations, and the publication of an investigator's project allows the information to be shared by the scientific community. Publications are often used as a measure of success of research work. In recent years, there has been growing interest in developing

\section{Biomed Central}

(c) 2013 Ramos et al.; licensee BioMed Central Ltd. This is an Open Access article distributed under the terms of the Creative Commons Attribution License (http://creativecommons.org/licenses/by/2.0), which permits unrestricted use, distribution, and reproduction in any medium, provided the original work is properly cited. 
scientific indicators capable of facilitating the analysis of the results of research activities [6].

The term "neglected tropical diseases", which was coined in the mid 1990s, has become a "brand-name" referring to a group of diseases which are especially endemic in low-income populations living in tropical and subtropical countries. Since then, there has been a growing interest in research and there are specific journals now available for getting this research published in the peer-reviewed literature [7]. There are international bibliometric studies in different fields of medicine [8-10] and/or tropical medicine [11-14]. There have been publications analyzing the research production in other neglected tropical diseases (NTD), such as schistosomiasis $[15,16]$, leprosy $[16,17]$, and Chagas disease $[16,18]$. As for leishmaniasis, one quantitative study analysing literature research output for the period between 1957 and 2006 using the Web of Science has been published [19]. There are other studies analyzing the scientific production and productivity of Iranian institutes in the field of leishmaniasis using the Medline database [20]. The PubMed database offers the possibility of analysing Medical Subject Headings (MeSH), MeSH categories articles and more biomedical journals than the Web of Science. Although the previous publications allowed a bibliometric analysis of research output on leishmaniasis, mapping leishmaniasis research to other aspects such as authorship and clinical forms of leishmaniasis is still pending. The aim of this study was to investigate leishmaniasis research output using PubMed over a period of 66 years (1945-2010) by journal of publication; animal or human $\mathrm{MeSH}$, taking advantage of the fact that in PubMed you can filter the search results by considering human or animal studies; forms of the disease and author production in terms of number of publications per author.

\section{Methods}

The Medline database, accessible free of charge through the PubMed platform, was selected as the most suitable for references to leishmaniasis publications due to its volume and coverage. Furthermore, it uses a controlled vocabulary, the Medical Subject Headings (MeSH) thesaurus, a hierarchical structure made up of 26,000 descriptors and over 213,000 entry terms, which allowed us to perform accurate searches. This database is easily accessible and widely used $[8,9,21]$. PubMed (http://www.ncbi. nlm.nih.gov/pubmed) was accessed online on 10 February 2012. The subject content analysis of records was conducted according to the MeSH structure. For retrieving documents, a search was composed with the MeSH terms or descriptors 'leishmaniasis' or 'Leishmania'. The study period was from 1 January 1945 to 31 December 2010, grouped by 5 -year increments because PubMed citations go back to 1945 . We did not consider any language or document type restriction in the search, in order to analyse publication patterns of all publications on Leishmaniasis.

The document type used in our study refers to the type of article and its financing. The impact factor of a journal and its ranking was obtained from the Journal Citation Report (JCR) 2010 Science Edition [22].

The productivity by country was analysed considering the number of papers and the percentage of world production. The institutional affiliation is only included for the first participating author since 1986 in the PubMed database in Journal articles and Review. Indicators of each country's productivity between 2001-2010 period were standardised with respect to the population, gross domestic product (GDP), gross national income (GNI) per capita and the health expenditure per capita. To calculate the publications per million inhabitants (population index), per billion of GDP (US dollars) (GDP index), per 100 US dollars of GNI per capita (GNI per capita index), and per 10 US dollars of health expenditure (HE) per capita (HE per capita index), data were obtained from Word Development Indicators from the online databases of the World Bank [23].

Based on geographic, scientific and economic criteria, the world was divided into seven regions: i) Europe; ii) North America (United States of America [USA] and Canada), iii) Latin America and the Caribbean; iv) North Africa and the Middle East (including Turkey); v) Africa; vi) Asia; and vii) Oceania. According to the MeSH term, the forms of diseases were the following: 'Leishmaniasis, visceral,'Leishmaniasis, cutaneous,' 'Leishmaniasis mucocutaneous', and 'Leishmaniasis diffuse cutaneous'. 'Leishmaniasis, cutaneous' and 'Leishmaniasis, diffuse cutaneous' have been included in PubMed since 1992.

The information obtained from the registers was introduced into a database using Microsoft Access 2007. A standardisation process was carried out to consolidate variations in author names. The criterion followed in this process was the occurrence of the institutional signature associated with the variations in names and surnames. Research output was analysed by country, geographic area, and forms of leishmaniasis. Publication authorship was analysed by the forms of leishmaniasis.

\section{Results}

In the PubMed database, 20,780 references were retrieved for the entire study period. There were 3,380 (16.3\%) publications from 1945 to $1980,3,567$ (17.2\%) from 1981 to $1989,5,566$ (26.8\%) from 1991 to 2000 , and 8,267 from 2001 to 2010 (39.8\%). Figure 1 shows the numbers of PubMed publications on leishmaniasis research during the 66-year study period in five-year periods. The five-year average increase of publications was $+10.5 \%$ throughout the study period, although this percentage was much higher from 1981 to 1985 (+81.1\%), 1961 to $1965(+42.9 \%)$, and from 1986 to 1990 (+42.3\%). This percentage was less from 


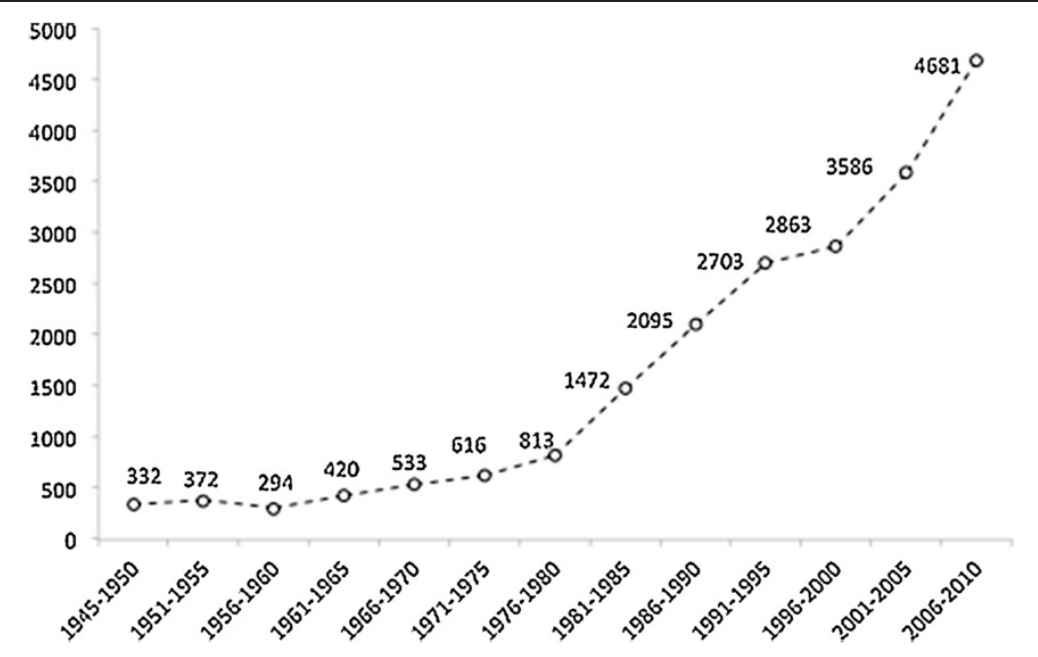

Figure 1 Number of leishmaniasis disease research publications in PubMed $(\bigcirc)$ between 1945 and 2010 per 5-year period.

1956 to $1960(-21.0 \%)$ and 1996 to $2000(+5.9 \%)$. After fitting the number of publications over time, a better fit was observed for a straight line (coefficient of determination for linear fit, $\mathrm{R}^{2}=0.91$ ) than for an exponential curve $\left(\mathrm{R}^{2}=0.81\right)$.

\section{Language of publication}

The primary language was English (82.8\%), followed by French (4.2\%), Portuguese (2.8\%), Spanish (2.6\%), Russian (2.5\%), German (1.3\%), Italian $(0.8 \%)$, Chinese $(0.5 \%)$, undetermined (1.8\%) and others $(0.8 \%)$.

\section{Journal of publication}

The 20,700 retrieved articles were published in 1,846 scientific journals. Eight journals accounted for $21.4 \%$ of the leishmaniasis journal literature. About one-half of the literature is concentrated in 50 journals, while the remaining half is scattered throughout 1,796 journals. Moreover, 743 journals published only one paper on leishmaniasis. Table 1 shows a list of the 50 journals with the highest number of papers published from 1945-2010, as well as their impact factors for the year 2010, subject category according to the JCR classification and language. Seven of these journals were not included in JCR because they did not have an impact factor, and three of these journals were not published in 2010. The remaining journals were included in at least one of 22 subject categories. Transactions of the Royal Society of Tropical Medicine and Hygiene leads the number of leishmaniasis documents published during 1945-2010 period $(n=1,018)$. The source journals mainly include the fields of parasitology $(n=13)$, immunology $(n=11)$, tropical medicine $(n=9)$, biochemistry and molecular biology $(\mathrm{n}=5)$ and microbiology $(\mathrm{n}=5)$, public health $(\mathrm{n}=5)$, among others.

\section{$\mathrm{MeSH}$}

The 30 most frequent MeSH words in documents published during the 1945-2010 period about leishmaniasis are shown in Table 2. Animals (41.2\%) was the predominant $\mathrm{MeSH}$, followed by Animals and Humans (29.0\%), and Humans (21.8\%). Figure 2 shows the numbers of PubMed publications on leishmaniasis research with MeSH Animals, Animals and Humans, and Humans during the 66-year study period by five-year periods. After fitting the number of publications over time, a better fit was observed for a straight line $\left(\mathrm{R}^{2}=0.98\right)$ for Animals; for Animals and Humans, a better fit was observed for an exponential curve $\left(R^{2}=0.97\right)$ than for a straight line $\left(\mathrm{R}^{2}=0.91\right)$; and for Humans, a better fit was observed for a line $\left(R^{2}=0.90\right)$ than for an exponential curve.

The MeSH visceral leishmaniasis, cutaneous leishmaniasis, mucocutaneous leishmaniasis, and diffuse cutaneous leishmaniasis were reported in $29.9 \%, 18.5 \%, 4.8 \%$ and $0.5 \%$, respectively. Figure 3 shows the numbers of PubMed publications by categories of leishmaniasis during the 66-year study period per five-year period. The main MeSH Leishmania species were L. donovani (13.9\%), L. major (9.3\%), L. infantum (6.7\%), L. mexicana (5.7\%), L. braziliensis (3.9\%), and L. tropica (3.9\%).

\section{Document type of publications}

Journal articles are the most common document type, accounting for about $86.5 \%$ of the total $(n=17,982)$. Review and Letter were the second and third most common, with 1,616 (7.8\%), and 1,008 (4.9\%) documents, respectively. Only $1.1 \%$ of the documents were subdivided into Randomized controlled trials $(\mathrm{n}=234), 0.8 \%$ into Clinical trial $(\mathrm{n}=157)$, and $0.3 \%$ into Controlled clinical trials $(\mathrm{n}=52)$. Case reports appeared in 2,171 $(10.4 \%)$ and Comparative study in 1,750 (8.4\%) documents. 
Table 1 The 50 journals with the highest number of leishmaniasis articles published during the 1945-2010 period

\begin{tabular}{|c|c|c|c|c|c|}
\hline Journal & $\begin{array}{l}\text { N. of } \\
\text { docs }\end{array}$ & $\%$ & $\begin{array}{l}\text { Impact factor } \\
2010\end{array}$ & Journal category (ranking) & Language \\
\hline \multirow{2}{*}{$\begin{array}{l}\text { Transactions of the Royal Society of Tropical } \\
\text { Medicine and Hygiene }\end{array}$} & \multirow[t]{2}{*}{1.018} & \multirow[t]{2}{*}{4.9} & \multirow[t]{2}{*}{2.832} & Public. Environmental \& Occupational Health (30 of 142) & \multirow{2}{*}{ Eng } \\
\hline & & & & Tropical Medicine (4 of 19) & \\
\hline \multirow{2}{*}{$\begin{array}{l}\text { The American Journal of Tropical Medicine } \\
\text { and Hygiene }\end{array}$} & \multirow[t]{2}{*}{679} & \multirow[t]{2}{*}{3.3} & \multirow[t]{2}{*}{2.446} & Public. Environmental \& Occupational Health (38 of 142) & \multirow{2}{*}{ Eng } \\
\hline & & & & Tropical Medicine (5 of 19) & \\
\hline \multirow[t]{2}{*}{ Molecular and Biochemical Parasitology } & \multirow[t]{2}{*}{599} & \multirow[t]{2}{*}{2.9} & \multirow[t]{2}{*}{2.875} & Biochemistry \& Molecular Biology (189 of 236) & \multirow{2}{*}{ Eng } \\
\hline & & & & Parasitology (6 of 32) & \\
\hline \multirow[t]{2}{*}{ Memórias do Instituto Oswaldo Cruz } & \multirow[t]{2}{*}{438} & \multirow[t]{2}{*}{2.1} & \multirow[t]{2}{*}{2.058} & Parasitology (13 of 32) & \multirow{2}{*}{ Eng } \\
\hline & & & & Tropical Medicine (7 of 19) & \\
\hline Experimental Parasitology & 428 & 2.1 & 1.869 & Parasitology (14 of 32) & Multi \\
\hline Journal of immunology (Baltimore. Md. : 1950) & 427 & 2.1 & 5.747 & Immunology (20 of 134) & Eng \\
\hline \multirow[t]{3}{*}{ Annals of Tropical Medicine and Parasitology } & \multirow[t]{3}{*}{426} & \multirow[t]{3}{*}{2.1} & \multirow[t]{3}{*}{1.579} & Parasitology (20 of 32) & \\
\hline & & & & Public. Environmental \& Occupational Health (86 of 142) & Eng \\
\hline & & & & Tropical Medicine (8 of 19) & \\
\hline Infection and Immunity & 423 & 2.0 & 4.098 & Immunology (33 of 134) & Eng \\
\hline & & & & Infectious Diseases (11 of 58) & Lity \\
\hline Meditsinskaia Parazitologiia i Parazitarnye Bolezni & 352 & 1.7 & $\mathrm{Nl}$ & - & Rus \\
\hline The Journal of Biological Chemistry & 295 & 1.4 & 5.328 & Biochemistry \& Molecular Biology (50 of 286) & Eng \\
\hline Acta Tropica & 291 & 1.4 & 2.262 & Parasitology (10 of 32) & \\
\hline & & & & Tropical Medicine (6 of 19) & Lity \\
\hline Revista da Sociedade Brasileira de Medicina Tropical & 277 & 1.3 & 0.580 & Tropical Medicine (14 of 19) & Mul \\
\hline Parasitology Research & 216 & 1.0 & 1.812 & Parasitology (15 of 32) & Eng \\
\hline Antimicrobial Agents and Chemotherapy & 211 & 1.0 & 4.672 & Microbiology (18 of 107) & End \\
\hline & & & & Pharmacology \& Pharmacy (26 of 252) & Liry \\
\hline The Journal of Parasitology & 203 & 1.0 & 1.208 & Parasitology (21 of 32) & Eng \\
\hline Parasitology & 201 & 1.0 & 2.522 & Parasitology (7 of 32) & Eng \\
\hline International Journal of Dermatology & 195 & 0.9 & 1.265 & Dermatology (36 of 55) & Eng \\
\hline The Journal of Infectious Diseases & 188 & 0.9 & 6.288 & Immunology (19 of 134) & \\
\hline & & & & Infectious Diseases (5 of 58) & Eng \\
\hline & & & & Microbiology (12 of 112) & \\
\hline Veterinary Parasitology & 187 & 0.9 & 2.331 & Parasitology (9 of 32) & En \\
\hline & & & & Veterinary Sciences (9 to 145) & Lrity \\
\hline Journal of the Egyptian Society of Parasitology & 181 & 0.9 & $\mathrm{Nl}$ & - & Eng \\
\hline Revista do Instituto de Medicina Tropical de São Paulo & 176 & 0.8 & 0.934 & Tropical Medicine (12 of 19) & Multi \\
\hline European Journal of Immunology & 166 & 0.8 & 4.942 & Immunology (22 of 134) & Eng \\
\hline Vaccine & 152 & 0.7 & 3.572 & Immunology (43 of 134) & Eng \\
\hline & & & & Medicine. Research \& Experimental (25 of 106) & Lrity \\
\hline International Journal for Parasitology & 149 & 0.7 & 3.822 & Parasitology (4 of 32) & Eng \\
\hline Clinical Infectious Diseases & 142 & 0.7 & 8.186 & Immunology (11 of 134) & \\
\hline & & & & Infectious Diseases (2 of 58) & Eng \\
\hline & & & & Microbiology (9 of 112) & \\
\hline Parasite Immunology & 138 & 0.7 & 2.328 & Immunology (8 of 134) & En \\
\hline & & & & Parasitology (8 of 32) & Lity \\
\hline $\begin{array}{l}\text { Proceedings of the National Academy of Sciences } \\
\text { of the United States of America }\end{array}$ & 129 & 0.6 & 9.971 & Multidisciplinary Sciences (3 of 59) & Eng \\
\hline
\end{tabular}


Table 1 The 50 journals with the highest number of leishmaniasis articles published during the 1945-2010 period (Continued)

\begin{tabular}{|c|c|c|c|c|c|}
\hline \multirow[t]{2}{*}{ The Journal of Experimental Medicine } & \multirow[t]{2}{*}{126} & \multirow[t]{2}{*}{0.6} & \multirow[t]{2}{*}{14.776} & Immunology (2 of 134) & \multirow{2}{*}{ Eng } \\
\hline & & & & Medicine. Research \& Experimental (5 of 106) & \\
\hline Clinical and Experimental Immunology & 122 & 0.6 & 3.134 & Immunology (56 of 134) & Eng \\
\hline $\begin{array}{l}\text { Bulletin de la Société de Pathologie Exotique } \\
\text { et de ses Filiales (a) }\end{array}$ & 122 & 0.6 & $\mathrm{Nl}$ & - & Fre \\
\hline Lancet & 121 & 0.6 & 33.633 & Medicine. General \& Internal (2 of 153) & Eng \\
\hline Journal of Clinical Microbiology & 116 & 0.6 & 4.220 & Microbiology (20 of 112) & \multirow[t]{2}{*}{ Eng } \\
\hline \multirow[t]{3}{*}{ Indian Journal of Medical Research } & \multirow[t]{3}{*}{112} & \multirow[t]{3}{*}{0.5} & \multirow[t]{3}{*}{1.826} & Immunology (106 of 134) & \\
\hline & & & & Medicine. General \& Internal (44 of 153) & \multirow[t]{2}{*}{ Eng } \\
\hline & & & & Medicine. Research \& Experimental (56 of 106) & \\
\hline \multirow[t]{2}{*}{ Tropical Medicine \& International Health } & \multirow[t]{2}{*}{109} & \multirow[t]{2}{*}{0.5} & \multirow[t]{2}{*}{2.967} & Public. Environmental \& Occupational Health (29 to 142) & \multirow{2}{*}{ Eng } \\
\hline & & & & Tropical Medicine (3 of 19) & \\
\hline The Journal of Protozoology (3)QUÉ ES ESTO & 105 & 0.5 & $\mathrm{Nl}$ & - & Eng \\
\hline East African Medical Journal & 95 & 0.5 & $\mathrm{Nl}$ & - & Eng \\
\hline \multirow[t]{2}{*}{ Journal of Medical Entomology } & \multirow[t]{2}{*}{94} & \multirow[t]{2}{*}{0.5} & \multirow[t]{2}{*}{1.925} & Entomology (12 of 83) & \multirow{2}{*}{ Eng } \\
\hline & & & & Veterinary Sciences (15 of 145) & \\
\hline Parassitologia & 91 & 0.4 & $\mathrm{Nl}$ & - & Ita \\
\hline Nucleic Acids Research & 90 & 0.4 & 3.836 & Biochemistry \& Molecular Biology (30 of 286) & Eng \\
\hline Journal of Communicable Diseases & 84 & 0.4 & $\mathrm{Nl}$ & - & Eng \\
\hline Annales de Parasitologie Humaine et Comparée (c) & 83 & 0.4 & $\mathrm{Nl}$ & - & Fre \\
\hline Trends in Parasitology & 82 & 0.4 & 4.906 & Parasitology (2 of 32) & Eng \\
\hline \multirow[t]{3}{*}{ Microbes and Infection } & \multirow[t]{3}{*}{82} & \multirow[t]{3}{*}{0.4} & \multirow[t]{3}{*}{2.726} & Immunology (70 of 134) & \\
\hline & & & & Microbiology (42 of 107) & \multirow[t]{2}{*}{ Eng } \\
\hline & & & & Virology (16 of 33) & \\
\hline Cadernos de Saúde Pública & 80 & 0.4 & 0.987 & $\begin{array}{l}\text { Public. Environmental \& Occupational Health (107 of } \\
\text { 142) }\end{array}$ & Por \\
\hline \multirow[t]{2}{*}{ PLoS Neglected Tropical Diseases } & \multirow[t]{2}{*}{80} & \multirow[t]{2}{*}{0.4} & \multirow[t]{2}{*}{4.752} & Parasitology (3 of 32) & bg \\
\hline & & & & Tropical Medicine (1 of 19) & Eng \\
\hline Journal of Medicinal Chemistry & 79 & 0.4 & 5.527 & Chemistry. Medicinal (3 of 54) & Eng \\
\hline Bioorganic \& Medicinal Chemistry & 76 & 0.4 & 2.906 & Biochemistry \& Molecular Biology (134 of 286) & \\
\hline & & & & Chemistry. Medicinal (15 of 54) & Eng \\
\hline & & & & Chemistry. Organic (16 of 56) & \\
\hline The Biochemical Journal & 75 & 0.4 & 5.016 & Biochemistry \& Molecular Biology (134 of 286) & Eng \\
\hline $\begin{array}{l}\text { Médecine Tropicale : Revue du Corps de Santé } \\
\text { Colonial }\end{array}$ & 75 & 0.4 & $\mathrm{Nl}$ & - & Fre \\
\hline Science (New York. N.Y.) & 75 & 0.4 & 31.377 & Multidisciplinary Sciences (2 of 59) & Eng \\
\hline
\end{tabular}

Their impact factors for the year 2010. Journal category with ranking from the Journal Citation Report and language of publication. NI: Not included in 2010 JCR Science Edition. Docs: documents.

Eng, English; Fre, French; Ita, Italian; Multi, Multi-language; Por, Portuguese; Spa, Spanish; Rus, Russian.

(a) Publication end year 1989.

(b) Publication end year 1992.

(c) Publication end year 1993.

\section{Publication by country}

The first author's institutional address was available for 13,973 of the 20,780 publication documents (67.2\%). One-hundred and seven countries published at least one paper. USA was the predominant country (16.8\%), followed by Brazil (14.9\%), India (9.0\%), the United Kingdom [UK] (7.1\%), France (5.8\%), Spain (5.3\%) and Germany (4.2\%). These seven countries contributed $63.1 \%$ of all research documents published during the study period (1945-2010) and 30 countries contributed 
Table 2 The 30 top Medical Subject Headings (MeSH) words in leishmaniasis articles published during the 1945-2010 period

\begin{tabular}{|c|c|c|}
\hline MeSH & N. of documents & $\%$ \\
\hline Animals & 8.564 & 41.2 \\
\hline Animals \& Humans & 6.036 & 29.0 \\
\hline Leishmaniasis. Visceral & 6.216 & 29.9 \\
\hline Male & 5.514 & 26.5 \\
\hline Female & 5.431 & 26.1 \\
\hline Leishmania & 5.034 & 24.2 \\
\hline Leishmaniasis & 4.991 & 24.0 \\
\hline Humans & 4.531 & 21.8 \\
\hline Mice & 3.852 & 18.5 \\
\hline Leishmaniasis. Cutaneous & 3.848 & 18.5 \\
\hline Adult & 3.295 & 15.9 \\
\hline Leishmania donovani & 2.896 & 13.9 \\
\hline Antiprotozoal Agents & 2.604 & 12.5 \\
\hline Mice. Inbred BALB C & 2.125 & 10.2 \\
\hline Child & 2.039 & 9.8 \\
\hline Leishmania major & 1.937 & 9.3 \\
\hline Adolescent & 1.825 & 8.8 \\
\hline Middle Aged & 1.807 & 8.7 \\
\hline Macrophages & 1.575 & 7.6 \\
\hline Dogs & 1.513 & 7.3 \\
\hline Molecular Sequence Data & 1.447 & 7.0 \\
\hline Antigens. Protozoan & 1.447 & 7.0 \\
\hline Child. Preschool & 1.428 & 6.9 \\
\hline Leishmania infantum & 1.402 & 6.7 \\
\hline Insect Vectors & 1.343 & 6.5 \\
\hline Protozoan Proteins & 1.233 & 5.9 \\
\hline Antibodies. Protozoan & 1.182 & 5.7 \\
\hline Leishmania mexicana & 1.182 & 5.7 \\
\hline Psychodidae & 1.126 & 5.4 \\
\hline Dog Diseases & 1.125 & 5.4 \\
\hline Cricetinae & 1.038 & 5.0 \\
\hline
\end{tabular}

92.6\%. Brazil leads the scientific publications between 2001 and 2010 (18.5\%), followed by the USA (13.5\%), India (10\%), UK (5.8\%) and Spain (5.5\%).

Table 3 ranks countries in crude numbers of retrieved articles between 2001 and 2010 and numbers corrected by population index, GDP index, GNI per capita index and HE per capita index. When normalised by population, the order of prominence was Israel, Switzerland, Tunisia, Malta and Spain. Normalised by GDP, we found that among low- and middle-income countries, Nepal, Tunisia, Ethiopia, Sudan and Kenya were the most productive. If we calculate the ratio of number of leishmaniasis publications to GNI per capita, India, Brazil, Ethiopia, Nepal and Iran were the most productive. When normalised by HE per capita, the leading order were overpopulated countries: India, Ethiopia, Pakistan, Brazil and Nepal.

Table 4 ranks countries in crude numbers of retrieved articles, stratified by forms of the leishmaniasis. For visceral leishmaniasis, the main countries were India, Brazil and Spain. Regarding cutaneous leishmaniasis, the countries leading the ranking were Brazil, the USA, and Germany. For mucocutaneous leishmaniasis, Brazil, USA and France led; meanwhile, for diffuse cutaneous leishmaniasis, leading countries were Brazil, Venezuela and USA.

\section{Publication by geographic area}

Europe was by far the most productive area in the field of leishmaniasis, responsible for $31.7 \%$ of all articles. Latin America and the Caribbean and North America ranked second and third, respectively, with $24.5 \%$ and $16.2 \%$ each (Table 3 ). The ranking corrected by population gives the first position to Oceania followed by North America. When normalised by GPD, GNI per capita and HE per capita, the order of prominence was Latin America and the Caribbean (Table 3).

Europe was the most productive in visceral leishmaniasis, followed by Asia. Latin America and the Caribbean ranked first in cutaneous, mucocutaneous and diffuse cutaneous leishmaniasis (Table 4).

Every world region increased their absolute production during the study period. Europe had more articles published each 5-year period, but their relative contribution fell during the last one, to $29.2 \%$. Latin America increased its absolute production during the study period and increased its relative contribution from $18.0 \%$ in 1986-1990 to $26.8 \%$ from 2006-2010. Asia increased its absolute production during the study period, and increased its relative contribution from $8.8 \%$ in 19861990 to $20.5 \%$ in 2006-2010. The relative contribution of North America decreased from $28.0 \%$ in $1986-1990$ to $14.4 \%$ in the 2006-2010 period. The relative contribution of North Africa and the Middle East, Africa and Oceania was similar during all 5-year periods (Figure 4).

\section{Authorship}

Table 5 ranks the 20 most productive authors in each form of the disease. For visceral leishmaniasis, the main author was S. Sundar, an Indian researcher $(\mathrm{n}=164$ documents), followed by H.W. Murray $(\mathrm{n}=91)$, a North American investigator, and L. Grandoni $(\mathrm{n}=87)$, an Italian scientist. For cutaneous leishmaniasis, the main author was P. Schott $(\mathrm{n}=62)$, a North American investigator, followed by F. Pratlong $(n=55)$, a researcher from France, and D.L. Sacks $(n=49)$, a North American scientist. In mucocutaneous leishmaniasis, P.D. Marsden $(n=68)$, a Brazilian, was 


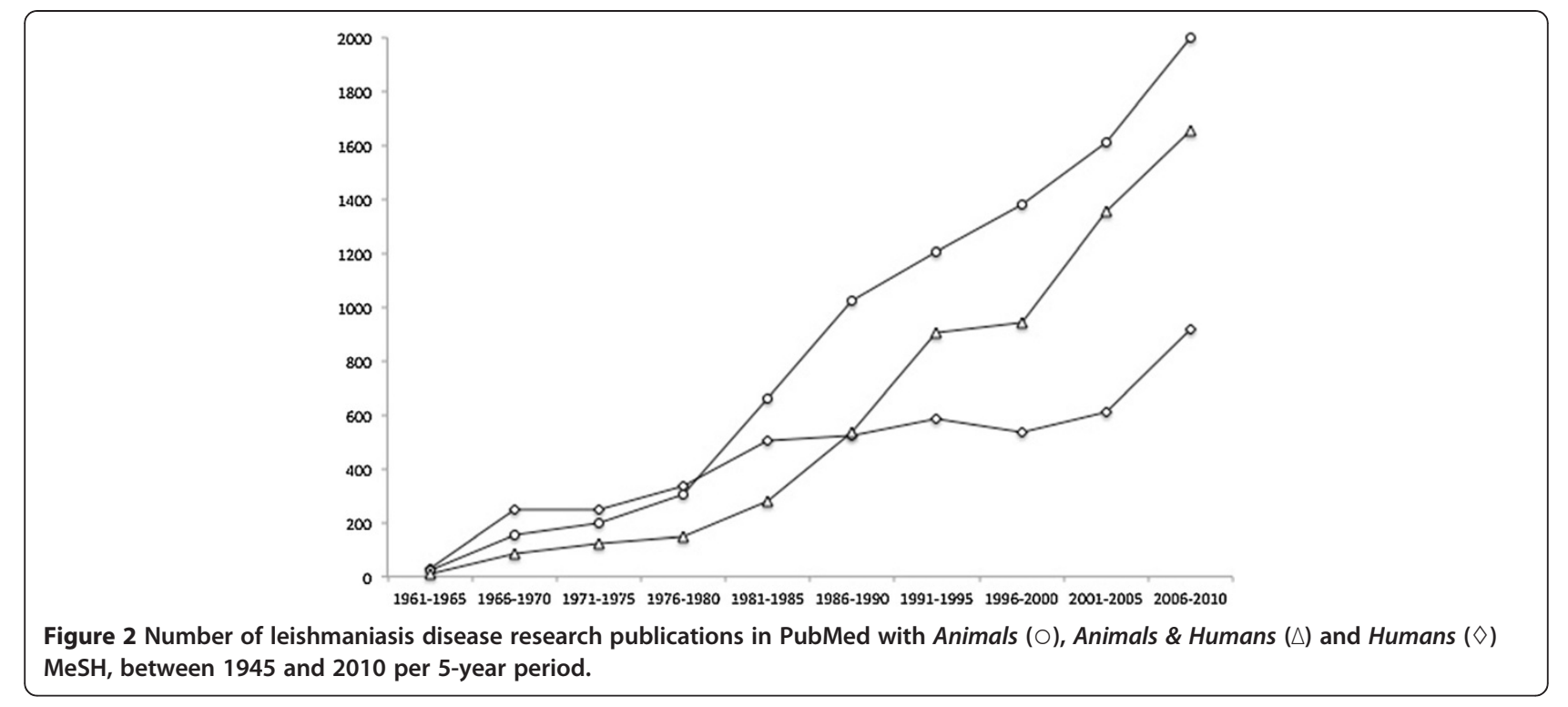

the leader, while for diffuse cutaneous leishmaniasis, leading were J.M. Costa, J. Convit and A.C. Saldanha $(\mathrm{n}=11$ each), among Latin American investigators.

\section{Discussion}

This study has shown an increase in the number of publications on leishmaniasis over the 1945-2010 period, which seems to be more pronounced than that observed in other neglected tropical diseases, such as American trypanosomiasis or leprosy $[17,18]$ and global tropical medicine [12-14]. Moreover, scientific publications on leprosy have experienced a reduced trend since the turn of the century [17]. This is probably related to different causes. First, the increase in estimating the prevalence of leishmaniasis seen in recent years [1]. Secondly, greater social awareness, including by the pharmaceutical industry and philanthropic world that has opened to these diseases, including the Bill \& Melinda Gates Foundation and other non-governmental organizations. Thirdly, we do not doubt the important steps taken by the World Health Organization (WHO) for inclusion in its health agenda an initiative to control the disease in endemic countries [2]. Fourthly, the therapeutic discoveries of drugs over the past 15 years (amphotericine B liposomic, miltefosine and paromomycin), or diagnosis procedures attract much attention on leishmaniasis $[2,4,24,25]$. Therefore, the continuous interest in the field and the incorporation of new journals in PubMed may have contributed to this linear increase. In this sense, two outstanding open access journals devoted to the study of Tropical Diseases have been launched in recent years: PLoS Neglected Tropical Diseases, started in 2007; and Parasites \& Vectors, established in 2008. Even

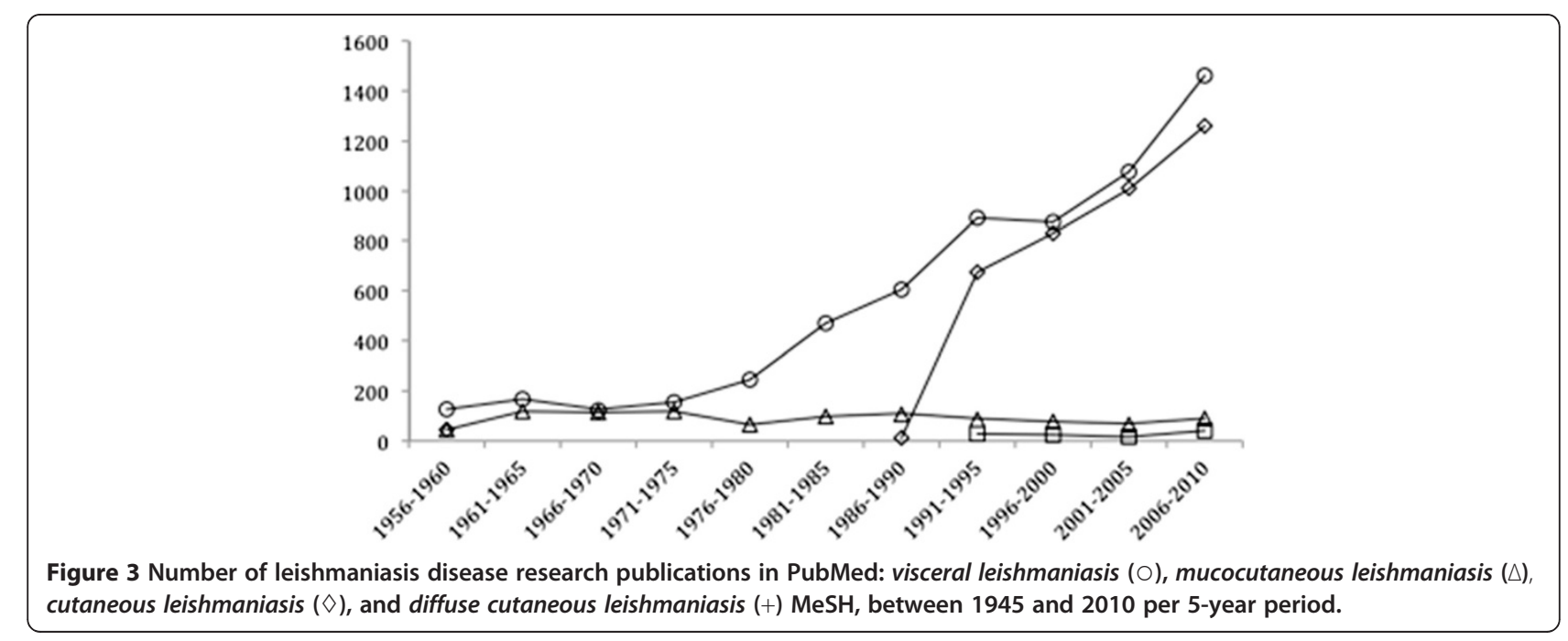


Table 3 Top 30 countries and world regions ranked according to total number of publications

\begin{tabular}{|c|c|c|c|c|c|c|c|c|c|c|}
\hline Country & $\begin{array}{l}\text { N. of } \\
\text { docs }\end{array}$ & $\%$ & Country & $\begin{array}{c}\text { Population } \\
\text { index }\end{array}$ & Country & $\begin{array}{c}\text { GDP } \\
\text { index** }\end{array}$ & Country & $\begin{array}{c}\text { GNI per } \\
\text { capita } \\
\text { index }^{* * *}\end{array}$ & Country & $\begin{array}{c}\text { HE per } \\
\text { capita } \\
\text { index }{ }^{* * *}\end{array}$ \\
\hline Brazil & 1.426 & 18.47 & Israel & 16.98 & Nepal & 4.44 & India & 96.50 & India & 227.35 \\
\hline USA & 1.040 & 13.47 & Switzerland & 14.28 & Tunisia & 3.51 & Brazil & 27.08 & Ethiopia & 39.00 \\
\hline India & 773 & 10.01 & Tunisia & 11.89 & Ethiopia & 2.41 & Ethiopia & 19.12 & Pakistan & 35.79 \\
\hline UK & 450 & 5.83 & Malta & 9.88 & Sudan & 1.59 & Nepal & 12.88 & Brazil & 29.52 \\
\hline Spain & 427 & 5.53 & Spain & 9.78 & Kenya & 1.37 & Iran & 9.46 & Nepal & 22.11 \\
\hline France & 376 & 4.87 & Greece & 8.63 & Brazil & 1.29 & Pakistan & 9.13 & Bangladesh & 13.33 \\
\hline Germany & 302 & 3.91 & Brazil & 7.65 & Iran & 1.25 & Sudan & 7.39 & Iran & 13.00 \\
\hline Italy & 291 & 3.77 & UK & 7.44 & Burkina Faso & 1.02 & Kenya & 5.21 & Kenya & 11.54 \\
\hline Iran & 264 & 3.42 & Belgium & 7.40 & Bolivia & 0.83 & Bangladesh & 3.99 & Sudan & 11.22 \\
\hline Canada & 213 & 2.76 & Portugal & 7.32 & India & 0.80 & Colombia & 3.77 & Tunisia & 6.32 \\
\hline Colombia & 133 & 1.72 & Canada & 6.55 & Sri Lanka & 0.79 & Tunisia & 3.73 & Colombia & 4.94 \\
\hline Tunisia & 120 & 1.55 & France & 5.94 & Colombia & 0.79 & USA & 2.41 & Sri Lanka & 4.42 \\
\hline Israel & 119 & 1.54 & Italy & 4.95 & Israel & 0.77 & China & 2.09 & China & 4.22 \\
\hline Turkey & 115 & 1.49 & Australia & 4.64 & Malta & 0.63 & Egypt & 1.94 & Egypt & 3.78 \\
\hline Venezuela & 111 & 1.44 & Czech Republic & 4.27 & Paraguay & 0.59 & Turkey & 1.73 & Turkey & 2.77 \\
\hline Switzerland & 107 & 1.39 & Netherlands & 4.22 & Pakistan & 0.56 & Spain & 1.73 & Venezuela & 2.75 \\
\hline Japan & 101 & 1.31 & Venezuela & 4.14 & Venezuela & 0.55 & Venezuela & 1.69 & Burkina Faso & 2.22 \\
\hline Australia & 96 & 1.24 & Iran & 3.76 & Afghanistan & 0.52 & Sri Lanka & 1.67 & Tanzania & 2.11 \\
\hline Greece & 96 & 1.24 & Germany & 3.67 & Cameroon & 0.46 & Burkina Faso & 1.55 & Iraq & 1.94 \\
\hline Belgium & 78 & 1.01 & Sweden & 3.63 & Albania & 0.46 & Afghanistan & 1.43 & Spain & 1.92 \\
\hline Portugal & 77 & 1.00 & Bahrain & 3.51 & Panama & 0.45 & UK & 1.23 & Cameroon & 1.67 \\
\hline Netherlands & 69 & 0.89 & USA & 3.50 & Senegal & 0.43 & Argentina & 1.19 & USA & 1.56 \\
\hline Argentina & 68 & 0.88 & Colombia & 3.07 & Surinam & 0.42 & Uganda & 1.17 & Morocco & 1.55 \\
\hline Pakistan & 68 & 0.88 & Denmark & 2.57 & Portugal & 0.40 & France & 1.11 & UK & 1.48 \\
\hline Mexico & 65 & 0.84 & Panama & 2.45 & Greece & 0.39 & Tanzania & 1.01 & Bolivia & 1.47 \\
\hline Sudan & 55 & 0.71 & Uruguay & 2.41 & Jordan & 0.38 & Italy & 0.99 & Afghanistan & 1.43 \\
\hline China & 46 & 0.60 & Austria & 2.07 & Uganda & 0.38 & Iraq & 0.96 & Mexico & 1.34 \\
\hline Czech Republic & 44 & 0.57 & Surinam & 2.00 & Iraq & 0.38 & Germany & 0.88 & Argentina & 1.33 \\
\hline Nepal & 42 & 0.54 & Cuba & 1.96 & Spain & 0.37 & Cameroon & 0.87 & Uganda & 1.29 \\
\hline Ethiopia & 39 & 0.51 & Cyprus & 1.93 & Uruguay & 0.36 & Mexico & 0.84 & Yemen & 1.28 \\
\hline World regions & $\begin{array}{l}\text { N. of } \\
\text { docs }\end{array}$ & $\%$ & World regions & $\begin{array}{c}\text { Population } \\
\text { index }\end{array}$ & World regions & $\begin{array}{c}\text { GDP } \\
\text { index** }\end{array}$ & World regions & $\begin{array}{c}\text { GNI per } \\
\text { capita } \\
\text { index }^{* * *}\end{array}$ & World regions & $\begin{array}{c}\text { HE per } \\
\text { capita } \\
\text { index }{ }^{* * * *} \\
\end{array}$ \\
\hline Europe & 2,452 & 31.75 & Oceania & 3.98 & $\begin{array}{l}\text { Latin America } \\
\text { and the } \\
\text { Caribbean }\end{array}$ & 0.62 & $\begin{array}{l}\text { Latin America } \\
\text { and the } \\
\text { Caribbean }\end{array}$ & 2.14 & $\begin{array}{l}\text { Latin America } \\
\text { and the } \\
\text { Caribbean }\end{array}$ & 2.87 \\
\hline $\begin{array}{l}\text { Latin America } \\
\text { and the } \\
\text { Caribbean }\end{array}$ & 1,893 & 24.51 & North America & 3.80 & North Africa & 0.31 & North America & 1.63 & Asia & 1.72 \\
\hline North America & 1,253 & 16.23 & $\begin{array}{l}\text { Latin America } \\
\text { and the } \\
\text { Caribbean }\end{array}$ & 3.57 & Africa & 0.30 & Asia & 0.84 & North America & 1.21 \\
\hline
\end{tabular}


Table 3 Top 30 countries and world regions ranked according to total number of publications (Continued)

\begin{tabular}{|c|c|c|c|c|c|c|c|c|c|c|}
\hline Asia & 1,397 & 18.09 & Europe & 3.50 & Europe & 0.16 & Africa & 0.74 & Africa & 1.12 \\
\hline North Africa & 459 & 5.94 & North Africa & 1.45 & Asia & 0.13 & Europe & 0.34 & North Africa & 0.72 \\
\hline Africa & 169 & 2.19 & Asia & 0.43 & Oceania & 0.12 & North Africa & 0.25 & Europe & 0.36 \\
\hline Oceania & 99 & 1.28 & Africa & 0.31 & North America & 0.09 & Oceania & 0.18 & Oceania & 0.18 \\
\hline
\end{tabular}

Publications per inhabitant, per gross domestic product (GDP), per gross national income (GNI) per capita, and health expenditure (HE) per capita in 7.851

leishmaniasis manuscripts with institutional address of the first author (2001-2010). Docs: documents.

* Number of publications per million of population.

** Number of publications per 1 billion US dollars of gross domestic product (GDP).

*** Number of publications per 100 US dollars of GNI per capita.

**** Number of publications per 10 US dollars of HE per capita.

though they do not appear in long-term bibliometric analyses, they are playing a major role in the area with a strong research activity.

Although the main language of leishmaniasis research output is English (82.8\%), this language is less common than other bibliometric studies based on PubMed, where 85-90\% of its documents are in English $[8,9]$. The other more important languages were French and Portuguese. Leishmaniasis is endemic in North Africa, France and Brazil [1], which might explain the prevalence of these languages with respect to others. For instance, the geographic distribution of the disease is important with the publication language about the disease [26]. For this, reviewing the journals in the original language of geographical distribution of the diseases is interesting.

Journal articles were the most commonly retrieved document type (approximately 90\%), similar to other bibliometric studies on NTDs and non-NTDs [8-10,17,18]. Although controlled trials offer the best evidence for medical intervention efficacy [27], in this study they represented only $0.3 \%$ of the documents, a figure lower than in other fields [8,9] and similar to other NTDs [18].

Nucleus journals usually contain articles with the highest impact in the area and thus, subscriptions to such journals in indexing and abstracting services would be justified scientifically [10,28]. Most top journals publishing on leishmaniasis were from the parasitology, immunology, and tropical medicine subject categories. The top journal was Transactions of the Royal Society of Tropical Medicine and Hygiene from the UK, while the American Journal of Tropical Medicine and Hygiene from the USA was second. Both included the public, environmental and occupational health and tropical medicine subject categories. The fourth and seventh journals were Memórias do Instituto Oswaldo Cruz and Annals of Tropical Medicine and Parasitology including the parasitology and tropical medicine subject categories. The third and fifth journals were Molecular and Biochemical Parasitology and Experimental Parasitology; both journals publish basic aspects of parasitology. The sixth and eighth journals were the Journal of Immunology and Infection and Immunology, respectively, both related to immunology.

USA was the leading country in publication output on leishmaniasis, like that which has also been described in other biomedical fields [8-10], although the number of leishmaniasis cases there is less than in South America. Brazil, a country with a high prevalence of leishmaniasis, led scientific production on leishmaniasis in Latin America. This can be attributed to the number of researchers and development of the country's scientific system, which has become the principal scientific reference for South America $[20,29]$. India, a country with a high prevalence of leishmaniasis, mainly in the state of Bihar [1,2,25,30], was the third country, and it led scientific production on leishmaniasis in Asia.

Leishmaniasis research in small countries, after adjusting for population, was led by Israel and Switzerland. Swiss publications came mainly from the WHO, especially from the Programmes of Prevention and Control of Leishmaniasis and Drugs for Neglected Diseases initiative [1,2]. Although institutions of the United Nations are not attributed to any country, the WHO is physical located in Geneva, Switzerland. The leading countries after adjusting for GDP were low- or middle-income countries with a higher prevalence of leishmaniasis, like Nepal, Tunisia, Kenya, Ethiopia and Sudan. When adjusting economic and demographic aspects (GNI per capita), the leading countries were low- and middle-income countries with a higher prevalence of leishmaniasis and overpopulated, like India, Ethiopia, Pakistan and Brazil [24,30,31].

In visceral leishmaniasis, the leading countries were India and Brazil, both with high prevalence. Spain was the third country, probably influenced by the association of visceral leishmaniasis and HIV infection [32]. In cutaneous leishmaniasis, Brazil, USA and Germany topped the rankings.

Europe was the world's leading area in scientific production on leishmaniasis. Although the disease load in Europe constitutes less than $0.2 \%$ of global cases of leishmaniasis, there are people with Leishmania infections living there, 
Table 4 Top 30 countries and word regions ranked according to total number of publications by forms of leishmaniasis disease

\begin{tabular}{|c|c|c|c|c|c|c|c|c|c|c|c|}
\hline \multicolumn{3}{|c|}{ Visceral leishmaniasis } & \multicolumn{3}{|c|}{ Cutaneous leishmaniasis } & \multicolumn{3}{|c|}{ Mucocutaneous leishmaniasis } & \multicolumn{3}{|c|}{ Diffuse cutaneous leishmaniasis } \\
\hline Country & $\begin{array}{l}\text { N. of } \\
\text { docs }\end{array}$ & $\%$ & Country & $\begin{array}{l}\text { N. of } \\
\text { docs }\end{array}$ & $\%$ & Country & $\begin{array}{l}\text { N. of } \\
\text { docs }\end{array}$ & $\%$ & Country & $\begin{array}{l}\text { N. of } \\
\text { docs }\end{array}$ & $\%$ \\
\hline India & 758 & 18.6 & Brazil & 667 & 19.0 & Brazil & 133 & 37.6 & Brazil & 34 & 33.3 \\
\hline Brazil & 583 & 14.3 & USA & 571 & 16.3 & USA & 33 & 9.3 & Venezuela & 13 & 12.7 \\
\hline Spain & 339 & 8.3 & Germany & 202 & 5.8 & France & 31 & 8.8 & USA & 10 & 9.8 \\
\hline USA & 308 & 7.5 & UK & 194 & 5.5 & Colombia & 23 & 6.5 & Mexico & 9 & 8.8 \\
\hline France & 250 & 6.1 & Iran & 183 & 5.2 & Venezuela & 18 & 5.1 & Germany & 5 & 4.9 \\
\hline Italy & 248 & 6.1 & France & 152 & 4.3 & Spain & 18 & 5.1 & India & 4 & 3.9 \\
\hline UK & 228 & 5.6 & Venezuela & 92 & 2.6 & UK & 17 & 4.8 & Colombia & 3 & 2.9 \\
\hline Germany & 91 & 2.2 & India & 91 & 2.6 & Bolivia & 13 & 3.7 & France & 3 & 2.9 \\
\hline Sudan & 91 & 2.2 & Spain & 82 & 2.3 & Peru & 11 & 3.1 & Italy & 2 & 2.0 \\
\hline Iran & 82 & 2.0 & Colombia & 78 & 2.2 & Sudan & 7 & 2.0 & Argentina & 2 & 2.0 \\
\hline Netherlands & 75 & 1.8 & Switzerland & 75 & 2.1 & Italy & 5 & 1.4 & Egypt & 2 & 2.0 \\
\hline Tunisia & 69 & 1.7 & Israel & 74 & 2.1 & Argentina & 5 & 1.4 & Iran & 2 & 2.0 \\
\hline Turkey & 60 & 1.5 & Tunisia & 70 & 2.0 & Germany & 5 & 1.4 & Sweden & 2 & 2.0 \\
\hline Greece & 59 & 1.4 & Japan & 66 & 1.9 & Switzerland & 4 & 1.1 & Japan & 1 & 1.0 \\
\hline Portugal & 58 & 1.4 & Turkey & 63 & 1.8 & India & 3 & 0.8 & Lebanon & 1 & 1.0 \\
\hline Canada & 57 & 1.4 & Egypt & 59 & 1.7 & Japan & 3 & 0.8 & Nigeria & 1 & 1.0 \\
\hline Belgium & 51 & 1.2 & Canada & 58 & 1.7 & Netherlands & 3 & 0.8 & Senegal & 1 & 1.0 \\
\hline Switzerland & 50 & 1.2 & Italy & 57 & 1.6 & Egypt & 2 & 0.6 & Spain & 1 & 1.0 \\
\hline Kenya & 46 & 1.1 & Pakistan & 50 & 1.4 & Tunisia & 2 & 0.6 & Burkina Faso & 1 & 1.0 \\
\hline Nepal & 45 & 1.1 & Mexico & 48 & 1.4 & Israel & 2 & 0.6 & Switzerland & 1 & 1.0 \\
\hline Ethiopia & 43 & 1.1 & Australia & 46 & 1.3 & Denmark & 2 & 0.6 & Bolivia & 1 & 1.0 \\
\hline Israel & 42 & 1.0 & Argentina & 43 & 1.2 & Pakistan & 2 & 0.6 & Australia & 1 & 1.0 \\
\hline Venezuela & 39 & 1.0 & Kenya & 38 & 1.1 & Greece & 2 & 0.6 & Tunisia & 1 & 1.0 \\
\hline China & 34 & 0.8 & Sudan & 34 & 1.0 & Nepal & 1 & 0.3 & Iraq & 1 & 1.0 \\
\hline Bangladesh & 30 & 0.7 & Saudi Arabia & 30 & 0.9 & Madagascar & 1 & 0.3 & - & - & - \\
\hline Denmark & 30 & 0.7 & Netherlands & 27 & 0.8 & Iran & 1 & 0.3 & - & - & - \\
\hline Egypt & 29 & 0.7 & Jordan & 22 & 0.6 & Panama & 1 & 0.3 & - & - & - \\
\hline Colombia & 26 & 0.6 & Denmark & 21 & 0.6 & Canada & 1 & 0.3 & - & - & - \\
\hline Saudi Arabia & 19 & 0.5 & Sri Lanka & 20 & 0.6 & Saudi Arabia & 1 & 0.3 & - & - & - \\
\hline Pakistan & 17 & 0.4 & Belgium & 19 & 0.5 & Sri Lanka & 1 & 0.3 & - & - & - \\
\hline World regions & $\begin{array}{l}\text { N. of } \\
\text { docs }\end{array}$ & $\%$ & World regions & $\begin{array}{l}\text { N. of } \\
\text { docs }\end{array}$ & $\%$ & World regions & $\begin{array}{l}\text { N. of } \\
\text { docs }\end{array}$ & $\%$ & World regions & $\begin{array}{l}\text { N. of } \\
\text { docs }\end{array}$ & $\%$ \\
\hline Europe & 1,554 & 38.1 & $\begin{array}{l}\text { Latin America and } \\
\text { the Caribbean }\end{array}$ & 987 & 28.1 & $\begin{array}{l}\text { Latin America and } \\
\text { the Caribbean }\end{array}$ & 205 & 57.9 & $\begin{array}{l}\text { Latin America and } \\
\text { the Caribbean }\end{array}$ & 62 & 17.5 \\
\hline Asia & 1,022 & 25.0 & Europe & 902 & 25.7 & Europe & 89 & 25.1 & Europe & 14 & 4.0 \\
\hline $\begin{array}{l}\text { Latin America and } \\
\text { the Caribbean }\end{array}$ & 674 & 16.5 & North America & 629 & 17.9 & North America & 34 & 9.6 & North America & 10 & 2.8 \\
\hline North America & 365 & 8.9 & Asia & 480 & 13.7 & Asia & 12 & 3.4 & Asia & 7 & 2.0 \\
\hline North Africa & 244 & 6.0 & North Africa & 354 & 10.1 & Africa & 8 & 2.3 & North Africa & 5 & 1.4 \\
\hline Africa & 204 & 5.0 & Africa & 113 & 3.2 & North Africa & 6 & 1.7 & Africa & 3 & 0.8 \\
\hline Oceania & 18 & 0.4 & Oceania & 47 & 1.3 & Oceania & 0 & 0.0 & Oceania & 1 & 0.3 \\
\hline Total & 4.081 & 100 & Total & 3,512 & 100 & Total & 354 & 100 & Total & 102 & 100 \\
\hline
\end{tabular}

Docs: documents. 


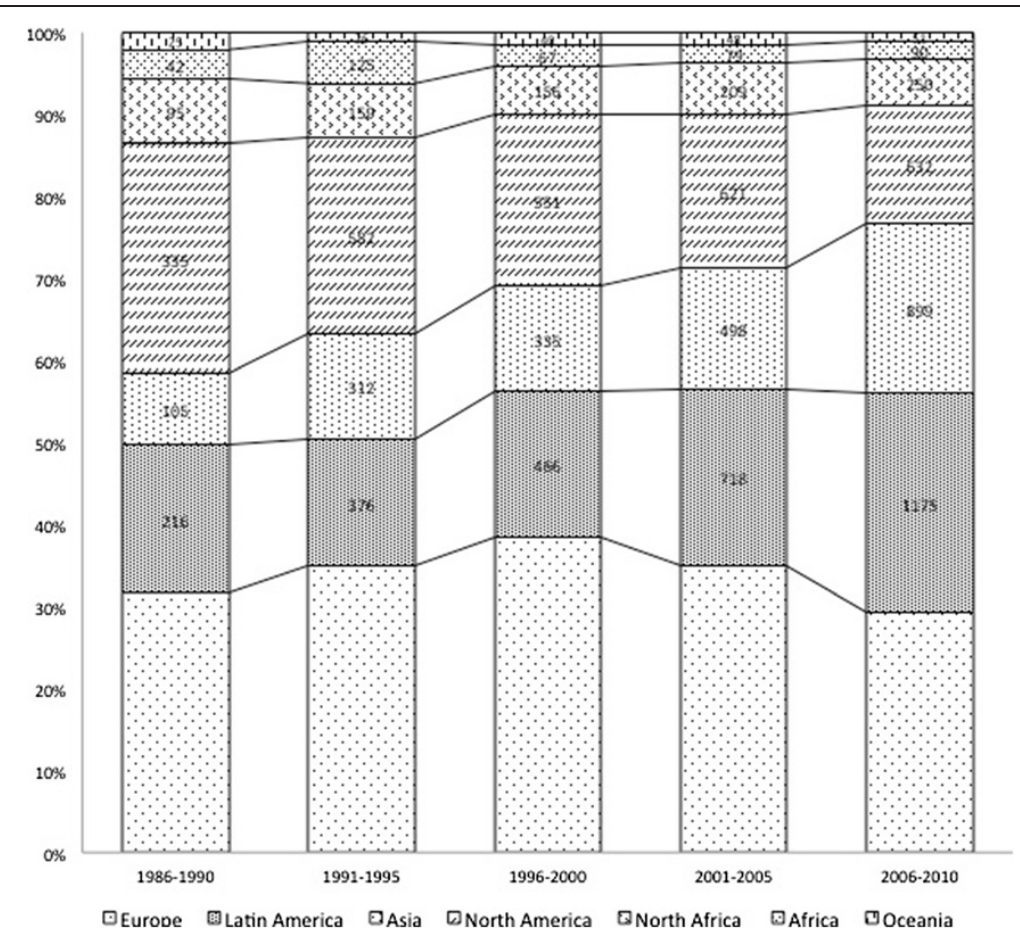

Figure 4 Research output of different world regions in leishmaniasis documents with institutional address of the first author published from 1986 to 2010 per 5-year period.

especially along the Mediterranean Coast [1]. Europe has a long tradition of agencies and institutions implementing research and health programmes in tropical medicine and parasitology [33-35], in addition to networks of scientists operating in these countries with other countries where leishmaniasis is endemic. Latin America was the world's second-leading area in scientific production on leishmaniasis. Its relative contribution increased to $26.8 \%$ in the last 5 -year study period. This is because of a high prevalence of this disease on this continent, the long lasting interest in this field in the Latin American countries, especially Brazil [19,24,29,35-37], and the incorporation of new Latin American journals in PubMed. North America was the world's third area. However, its relative contribution decreased to $14.4 \%$ in the $2006-2010$ period. A decreased contribution from North America also occurred in other biomedical fields such as tuberculosis [8]. The absolute and relative contribution from Asia increased in our study from 105 (8.8\%) in 1986-1990 to 899 (20.5\%) in the 20062010 period. This increasing Asian contribution has been seen in other scientific fields because of their improving research, including many leishmaniasis clinical trials conducted on the Indian subcontinent, and increasing incorporation of new Asians journals in PubMed [38]. The relative contribution from North Africa and the Middle East, Africa and Oceania was similar during all 5-year periods.
Europe and North America are at the vanguard of scientific excellence and development, and should increase their collaboration with scientific publications in developing countries, especially from North Africa and the Middle East and Africa in the field of leishmaniasis. Europe was the world leader in visceral leishmaniasis, followed by Asia. However, Latin America and the Caribbean ranked first in cutaneous, mucocutaneous and diffuse cutaneous leishmaniasis.

PubMed and the Science Citation Index were found to be the most suitable databases for searching and retrieving references for bibliometric studies $[8,21]$. We used the PubMed database because it is easily accessible and widely used, it uses a controlled vocabulary for indexing and recovering documents $[8,9,39]$, and the index journal in Medline has a certain criteria for quality $[16,40]$. However, the method we used may have several limitations that have been explained in other publications [18]. For example, the database mainly includes journals published in English, and journals in other languages are less likely to be found on PubMed. However, this database has more non-English journals than the Web of Science database [41]. Another limitation is that in PubMed, only the address of the first author appears in the journal articles, whereas in letters and editorials, the address field is not recorded, and the address has only been included since 1986 and systematically ever since. For instance, estimating the quantity of 
Table 5 Twenty most-productive authors ranked according to total number of publications by forms of the disease

\begin{tabular}{|c|c|c|c|c|c|c|c|c|c|c|c|}
\hline \multicolumn{3}{|c|}{ Visceral leishmaniasis } & \multicolumn{3}{|c|}{ Cutaneous leishmaniasis } & \multicolumn{3}{|c|}{ Mucocutaneous leishmaniasis } & \multicolumn{3}{|c|}{ Diffuse cutaneous leishmaniasis } \\
\hline Author & N. of docs & $\%$ & Author & N. of docs & $\%$ & Author & N. of docs & $\%$ & Author & N. of docs & $\%$ \\
\hline Sundar. S & 164 & 3.9 & Scott. Phillip & 62 & 1.8 & Marsden. Philip D & 68 & 19.2 & Costa. J M & 11 & 3.2 \\
\hline Murray. Henry W & 91 & 2.2 & Pratlong. Francine & 55 & 1.6 & Carvalho. Edgar M & 30 & 8.5 & Convit. Jacinto & 11 & 3.2 \\
\hline Gradoni. Luigi & 87 & 2.1 & Sacks. David L & 49 & 1.4 & Lainson. Ralph & 28 & 7.9 & Saldanha. Ana Cr & 11 & 3.2 \\
\hline Thakur. Chandreshwar P & 76 & 1.9 & Barral. Aldina M & 47 & 1.3 & Llanos Cuentas. E A & 28 & 7.9 & Barral. Aldina M & 10 & 2.9 \\
\hline Boelaert. Marleen & 73 & 1.8 & Carvalho. Edgar M & 47 & 1.3 & Cuba. C C & 23 & 6.5 & Carvalho. Edgar M & 9 & 2.6 \\
\hline El Hassan. Ahmed M & 73 & 1.8 & Dedet. Jean Pierre & 47 & 1.3 & Convit. Jacinto & 23 & 6.5 & Becker. I & 6 & 1.7 \\
\hline Gramiccia. Marina & 62 & 1.5 & Louis. Jacques A & 40 & 1.1 & Shaw. Jeffrey J & 21 & 5.9 & Ulrich. Marian & 6 & 1.7 \\
\hline Pratlong. Francine & 62 & 1.5 & Röllinghoff. Martin & 40 & 1.1 & Dedet. Jean Pi & 20 & 5.6 & Barral Netto. Manoel & 5 & 1.4 \\
\hline Alvar. Jorge & 60 & 1.5 & Locksley. Richard M & 40 & 1.1 & Costa. J M & 19 & 5.4 & Bittencourt. Achiléa L & 5 & 1.4 \\
\hline Marty. Pierre & 56 & 1.4 & Mayrink. Wilson & 38 & 1.1 & Barreto. A C & 19 & 5.4 & Tapia. Felix J & 5 & 1.4 \\
\hline Dedet. Jean P & 55 & 1.3 & Handman. Emanuela & 37 & 1.1 & Netto. Eduardo M & 19 & 5.4 & Galvão. C E & 4 & 1.2 \\
\hline Kaye. Paul M & 53 & 1.3 & Launois. Pascal & 35 & 1.0 & Saravia. Nancy G & 18 & 5.1 & Cáceres Dittmar. G & 4 & 1.2 \\
\hline Kager. Piet A & 52 & 1.3 & Barral Netto. Manoel & 35 & 1.0 & Pirmez. Claude & 17 & 4.8 & Pratlong. Francine & 4 & 1.2 \\
\hline Reed. Steven G & 50 & 1.2 & El Hassan. Ahmed M & 35 & 1.0 & Grimaldi Júnior. Gabriel & 16 & 4.5 & Pacheco de Almeida. Roque & 3 & 0.9 \\
\hline Rijal. Suman & 50 & 1.2 & Titus. Richard G & 34 & 1.0 & Barral. Aldina Maria P & 16 & 4.5 & Dedet. Jean P & 3 & 0.9 \\
\hline Badaró. Roberto & 47 & 1.2 & Llanos Cuentas. E A & 32 & 0.9 & Lessa. Hélio Andrade & 16 & 4.5 & Meyer Fernandes. José R & 3 & 0.9 \\
\hline Carvalho. Edgar M & 46 & 1.1 & Khamesipour. Ali & 30 & 0.9 & Furtado. T A & 14 & 4.0 & Machado. Paulo R L & 3 & 0.9 \\
\hline Davidson. Robert N & 41 & 1.0 & Shaw. Jeffrey Jon & 30 & 0.9 & Sampaio. Raimunda N R & 13 & 3.7 & Pérez Montfort. Ruy & 3 & 0.9 \\
\hline Croft. Simon L & 41 & 1.0 & Ramesh. Venkatesh & 29 & 0.8 & Mayrink. Wilson & 13 & 3.7 & Guimarães. Luis H & 3 & 0.9 \\
\hline Pearson. Richard D & 41 & 1.0 & Moll. Heidrun & 28 & 0.8 & Christensen. H A & 13 & 3.7 & Costa. Jackson Maurício L & 3 & 0.9 \\
\hline
\end{tabular}


articles resulting from multinational collaborations was not possible. This may cause some problems when estimating research productivity from developing countries that work in collaboration with scientists from a developed country. Even though the bibliometric methodology used may present some limitations and the results could, in some way, be biased $[9,40]$, we believe that this study represents a useful tool for scientists and public health policy makers in planning and organizing research in the field of leishmaniasis. We should emphasize that other authors should employ the method we used to find research production, so that our results may be comparable to others in the future.

\section{Conclusion}

In conclusion, we have found an increase in the number of publications in the field of leishmaniasis disease. Authors affiliated to institutions in USA and Brazil led scientific production on leishmaniasis research. Efforts should be made to help developing countries with the highest prevalence of leishmaniasis develop scientific research networks (collaborative platforms) with North American and/or European countries in order to increase research with interdisciplinary teams [42].

\section{Competing interests}

The authors declare that they have no competing interests.

\section{Authors' contributions}

JMR and GGA participated in the design and co-ordination of the study, performed the analysis, and drafted and prepared the paper. JMR, GGA, and MBP participated in the analysis. All authors read and approved the final document.

\section{Acknowledgements}

We want to thank Dr. Jorge Alvar (Department for the Control of Neglected Tropical Diseases (HTM/NTD/IDM), Leishmaniasis Control Program, the World Health Organization, Geneva, Switzerland) for his critical reading of this article and his comments.

\section{Author details}

${ }^{1}$ Department of Internal Medicine, Hospital General Universitario de Alicante, Alicante, Spain. ${ }^{2}$ Department of Medicine, Universidad Miguel Hernández de Elche, Alicante, Spain. ${ }^{3}$ Department of History of Science and

Documentation, Universitat de València, Facultad de Medicina y

Odontología, Valencia, Spain. ${ }^{4}$ Universitat de València, Valencia, Spain.

Received: 20 November 2012 Accepted: 20 February 2013

Published: 7 March 2013

\section{References}

1. WHO: Control of the leishmaniases. WHO Tec Rep Ser 2010, 949:1-186.

2. Alvar J, Vélez ID, Bern C, Herrero M, Desjeux P, Cano J, Jannin J, Den Boer M, WHO Leishmaniasis Control Team: Leishmaniasis worldwide and global estimates of its incidence. PLoS One 2012, 7:e35671.

3. Alvar J, Yactayo S, Bern C: Leishmaniasis and poverty. Trends Parasitol 2006, 22:552-557.

4. Chappuis F, Sundar S, Hailu A, Ghalib H, Rijal S, Peeling RW, Alvar J, Boelaert M: Visceral leishmaniasis: what are the needs for diagnosis, treatment and control? Nat Rev Microbiol 2007, 5:873-882.

5. Den Boer M, Argaw D, Jannin J, Alvar J: Leishmaniasis impact and treatment access. Clin Microbiol Infect 2011, 17:1471-1477.

6. Hefler L, Tempfer C, Kainz C: Geography of biomedical publications in the European Union, 1990-98. Lancet 1856, 1999:353.
7. Utzinger J, Becker SL, Knopp S, Blum J, Neumayr AL, Keiser J, Hatz CF: Neglected tropical diseases: diagnosis, clinical management, treatment and control. Swiss Med Wkly 2012, 142:W13727.

8. Ramos JM, Padilla S, Masia M, Gutiérrez F: A bibliometric analysis of tuberculosis research indexed in PubMed (1997-2006). Int J Tuberc Lung Dis 2008, 12:1461-1468.

9. Vioque J, Ramos JM, Navarrete-Muñoz EM, García-de-la-Hera M: A bibliometric study of scientific literature on obesity research in PubMed (1988-2007). Obes Rev 2010, 11:603-611.

10. Zheng HC, Yan L, Cui L, Guan YF, Takano Y: Mapping the history and current situation of research on John Cunningham virus - a bibliometric analysis. BMC Infect Dis 2009, 9:28.

11. Keiser J, Utzinger J, Tanner $M$, Singer $B H$ : Representation of authors and editors from countries with different human development indexes in the leading literature on tropical medicine: survey of current evidence. BMJ 2004, 328:1229-1232.

12. Falagas ME, Karavasiou Al, Bliziotis IA: A bibliometric analysis of global trends of research productivity in tropical medicine. Acta Trop 2006, 99:155-159.

13. Glover SW, Bowen SL: Bibliometric analysis of research published in Tropical Medicine and International Health 1996-2003. Trop Med Int Health 2004, 9:1327-1330.

14. Keiser J, Utzinger J: Trends in the core literature on tropical medicine: a bibliometric analysis from 1952-2002. Scientometrics 2005, 62:351-365.

15. Costa Lima JA, Schmitt Rosa CM, Piegas MH, Peixinho A, Schmidt A, De Lemos AA B, De Souza CA M: Analysis of scientific information published in Brazil in 5 years on Chagas disease, schistosomiasis, malaria, leishmaniasis and filariasis. Educ Med Salud 1985, 19:209-226.

16. Morel CM, Serruya SJ, Penna GO, Guimarães R: Co-authorship network analysis: a powerful tool for strategic planning of research, development and capacity building programs on neglected diseases. PLOS Negl Trop Dis 2009, 3:e501.

17. Schoonbaert $D$, Demedts $V$ : Analysis of the leprosy literature indexed in Medline (1950-2007). Lepr Rev 2008, 79:387-400.

18. Ramos JM, Alcaide G G, Gascón J, Gutiérrez F: González Alcaide G, Gascón J, Gutiérrez F: Mapping of Chagas disease research: analysis of publications in the period between 1940 and 2009. Rev Soc Bras Med Trop 2012, 44:708-716.

19. Al-Mutawakel K, Scutaru C, Shami A, Sakr M, Groneberg D, Quarcoo D: Scientometric analysis of the world-wide research efforts concerning leishmaniasis. Parasit Vectors 2010, 3:14.

20. Fallah $\mathrm{E}$, Biglu $\mathrm{MH}$ : Scientific production of leishmaniasis in PubMed: Impact of Iranian institutes. Int J Adv Pharm Sci 2011, 2:1-7.

21. Anders ME, Evans DP: Comparison of PubMed and Google Scholar literature searches. Respir Care 2010, 55:578-583.

22. ISI, Institute for Scientific Information: Web of Knowledge. http://wwwisinet.com.

23. Word Development Indicators. 2010. http://data.worldbank.org/indicator

24. Oliveira E, Saliba SW, Andrade CF, Rabello A: Direct agglutination test (DAT): improvement of biosafety for laboratory diagnosis of visceral leishmaniasis. Trans R Soc Trop Med Hyg 2011, 105:414-416.

25. Sundar S, Sinha PK, Verma DK, Kumar N, Alam S, Pandey K, Kumari P Ravidas V, Chakravarty J, Verma N, Berman J, Ghalib H, Arana B: Ambisome plus miltefosine for Indian patients with kala-azar. Trans $R$ Soc Trop Med Hyg 2011, 105:115-117.

26. Williams JR, Bórquez A, Basáñez MG: Hispanic Latin America, Spain and the Spanish-speaking Caribbean: a rich source of reference material for public health, epidemiology and tropical medicine. Emerg Themes Epidemiol 2008, 5:17.

27. Tsay MY, Yang YH: Bibliometric analysis of the literature of randomized controlled trials. J Med Libr Assoc 2005, 93:450-458.

28. López-Illescas C, De Moya-Anegón F, Moed HF: The actual citation impact of European oncological research. Eur J Cancer 2008, 44:228-236.

29. Almeida EA, Ramos Junior AN, Correia D, Shikanai Yasuda MA: Rede brasileira de atenção e estudos na co-infecção trypanosoma cruzi/HIV e em outras condições de imunossupressão. Rev Soc Bras Med Trop 2009, 42:605-608.

30. Das VN, Siddiqui NA, Verma RB, Topno RK, Singh D, Das S, Ranjan A, Pandey K, Kumar N, Das P: Asymptomatic infection of visceral leishmaniasis in hyperendemic areas of Vaishali district, Bihar, India: a challenge to kala-azar elimination programmes. Trans R Soc Trop Med Hyg 2011, 105:661-666. 
31. Lemma W, Erenso G, Gadisa E, Balkew M, Gebre-Michael T, Hailu A: A zoonotic focus of cutaneous leishmaniasis in Addis Ababa, Ethiopia. Parasit Vectors 2009, 2:60.

32. Alvar J, Aparicio P, Aseffa A, Den Boer M, Cañavate C, Dedet JP, Gradoni L, Ter Horst R, López-Vélez R, Moreno J: The relationship between leishmaniasis and AIDS: the second 10 years. Clin Microbiol Rev 2008, 21:334-359.

33. Harmer A: Understanding change in global health policy: ideas, discourse and networks. Glob Public Health 2011, 6:703-718.

34. Palatnik-de-Sousa CB, Day MJ: One Health: the global challenge of epidemic and endemic leishmaniasis. Parasit Vectors 2011, 4:197.

35. Molyneux DH, Malecela MN: Neglected tropical diseases and the millennium development goals: why the "other diseases" matter: reality versus rhetoric. Parasit Vectors 2011, 4:234.

36. Hotez PJ, Bottazzi ME, Franco-Paredes C, Ault SK, Periago MR: The neglected tropical diseases of Latin America and the Caribbean: a review of disease burden and distribution and a roadmap for control and elimination. PLoS Negl Trop Dis 2008, 2:e300.

37. González-Alcaide G, Park J, Huamaní C, Gascón J, Ramos JM: Scientific authorships and collaboration network analysis on Chagas disease: papers indexed in PubMed (1940-2009). Rev Inst Med Trop Sao Paulo 2012, 54:219-228.

38. Chen JH, Wang H, Chen JX, Bergquist R, Tanner M, Utzinger J, Zhou XN: Frontiers of parasitology research inthe People's Republic of China: infection, diagnosis, protection andsurveillance. Parasit Vectors 2012, 5:221.

39. Falagas ME, Papastamataki PA, Bliziotis IA: A bibliometric analysis of research productivity in parasitology by different world regions during a 9-year period (1995-2003). BMC Infect Dis 2006, 6:56.

40. Rollin RL, Darmoni S, Caillard JF, Gehanno JF: Searching for high-quality articles about intervention studies in occupational health: what is really missed when using only the Medline database? Scand J Work Environ Health 2010, 36:484-487.

41. Sevinc A: Multilingual approach to "Web of Science". J Natl Med Assoc 2005, 97:116-117.

42. Falagas ME, Panos G: Implications of findings of bibliometric analyses in parasitology. Trends Parasitol 2007, 23:12-13.

doi:10.1186/1756-3305-6-55

Cite this article as: Ramos et al:: Bibliometric analysis of leishmaniasis research in Medline (1945-2010). Parasites \& Vectors 2013 6:55.

\section{Submit your next manuscript to BioMed Central and take full advantage of:}

- Convenient online submission

- Thorough peer review

- No space constraints or color figure charges

- Immediate publication on acceptance

- Inclusion in PubMed, CAS, Scopus and Google Scholar

- Research which is freely available for redistribution 